powerful instrument of research-one which made it possible to photograph spectra directly without the use of prisms or lenses and with a greatly increased dispersion and resolving power. In 1888 he published a photographic map of the normal solar spectrum, in 1893 a table of standard wave-lengths, and in 1895-97 a table of solar wave-lengths. For his dis. coveries and investigations Rowland received the Rumford, the Draper and the Matteucci Medals and was honoured in many ways by societies and universities. Besides being a great investigator, he was a great teacher, kindling in his students an enthusiasm approaching his own. His work was always dis. tinguished for refinement and accuracy; and withal he possessed the true scientific temperament. "For myself," he said once, "I value in a scientific mind most of all that love of truth, that care in its pursuit and that humility of mind which makes the possibility of error always present, more than any other quality. This is the mind which has built up modern science to its present perfection, which has laid one stone upon the other with such care that it to-day offers to the world the most complete monument of human reason." Rowland died at his house in Baltimore on April 16, 1901. His body was cremated and his ashes buried beneath his famous ruling engine. His library was in 1903 given by his widow to the Johns Hopkins University.

\section{Mathematics at Ibadan}

The chair of mathematics at University College, Ibadan, Nigeria, has now been filled by the election of Dr. F. V. Atkinson. Educated at St. Paul's School and at the Queen's College, Oxford (of which he was an open scholar during 1934-37), Dr. Atkinson was later a Senior Demy of Magdalen. During the War he served with the Army in India, reaching the rank of major, and he returned to Oxford in 1946 as lecturer in mathematics at Christchurch. Dr. Atkinson's work has been chiefly concerned with the analytical theory of numbers, and the properties of the Riemann

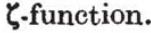

\section{Reading Institute of Education}

AN Institute of Education has been established in Reading as the area training organisation for Berkshire, Buckinghamshire, Hampshire, Oxfordshire, West Sussex and Reading. The scheme for the Institute provides for a Board of Governors drawn in equal proportions from the local education authorities in the area and from the University of Reading. The Minister of Education has appointed Sir Frank Stenton, vice-chancellor of the University, as chairman. The principal objects of the Institute are to further the training of teachers and other persons intending to engage in educational work in the area ; to foster close relations between the corporate mem. bers of the Institute (at present, the University of Reading, the county councils and county borough councils in the area and the training colleges in the area, namely, Culham, Bishop Otter, Easthampstead Park and Newlands Park); and to establish an educational centre for the promotion of the educational interests of students and teachers and other persons professionally concerned with or interested in education in the Institute area. The Institute will be established in or near Reading, and a search for suitable accommodation has already begun; ultimately it is hoped that the Institute will have a new building designed for the purpose. Mr. C. R. E. Gillett has been appointed director of the Institute.

\section{Sources of Technical Assistance}

A SURVEy of the technical assistance available for economic development in the United Nations and the Specialized Agencies has been prepared by the secretariat for the second session of the Sub-Commission on Economic Development of the Economic and Employment Commission (London : H.M. Sta. tionery Office. United Nations, E/CN.1/Sub. 3/22. June 2, 1948). Its immediate purpose is to facilitate examination of provisions currently be ing made for such assistance to members of the United Nations in their programmes of economic development, and particularly to assist the SubCommission in considering measures for increasing the availability and effectiveness of such technical assistance. Its scope is limited to those activities, excluding the provision of funds and relief suppljes, which are designed to assist economic development; provisions for technical assistance in the sphere of social welfare are not described in detail. The Survey gives a very clear but concise account of the types of assistance available, including that in the form of research and information, as well as international training, panels and conferences; and also of the sources of assistance. It then revizws in succession the various fields such as agriculture, forestry and forest products, fisheries, education and technical training, labour and employment, health, nutrition and safety, finance and currency, or statisties in which such assistance might be required. The Survey contains nothing that is new ; but gives a convenient and impressive picture of the elaborate and interlocking organisation for world co-operation which has already been built up, and which could be used if the will to do so were genuine and widespread.

\section{German Hydrographic Journal}

ReFerence was made in Nature of September 4, p. 364, to the first issue of the Deutsche Hydro. graphische Zeitschrift. The next two numbers have now appeared: Vol. 1, No. 2/3, June 1948; and Vol. 1, No. 4, August 1948. The former contains articles on problems of marine geology, coastal geodesy, terrestrial magnetism and oceanography, whereas No. 4 is completely devoted to oceanographical and tidal problems. An essay.by O. Pratje on the bottom sediments of the southern and middle Baltic and their importance for the interpretation of fossil sediments is based on about a thousand bottom samples which had been collected in the years just before the War. It is accompanied by detailed charts and profiles. F. Rudolf Jung examines the limits of applicability of transit-bearing and of the trigonometrical determination of distances in the technique of marine surveying, and gives numerical and geographical aids for the practical work in question. F. Errulat deals with the mean intensity of great geomagnetic disturbances as dependent on geomagnetic latitude, and finds interesting relations with the results of J. Bartels. G. Neumann writes on resonance-oscillations of bights and on the mouth correction for seiches ; his treatment of the Frische Haff agrees well with results which $H$. Lettau had derived from the registrations of tide gauges. F. Model discusses the thickness of the ice on the Alster in Hamburg towards the end of the severe winter of 1946-47. On the open basin a thickness of $51-56 \mathrm{~cm}$. was found ; below a rather broad and low bridge it fell to only $12 \mathrm{~cm}$. G. Wust, studying once again the temperature-inversion in the deep waters of the South Atlantic, finds a remarkably close association 